\title{
Factors affecting influenza vaccination decisions in patients with cardiovascular diseases - selected aspects of research
}

\author{
Agnieszka Katarzyna Choińska', Małgorzata Poltz-Dacewicz ${ }^{2}$ \\ ${ }^{1}$ Medical University, Białystok, Poland \\ ${ }^{2}$ Medical University, Lublin, Poland
}

Choińska AK, Poltz-Dacewicz M. Factors affecting influenza vaccination decisions in patients with cardiovascular diseases - selected aspects of research. J Pre-Clin Clin Res. 2019; 13(1): 19-25. doi: 10.26444/jpccr/102433

\begin{abstract}
Objective. The article aims to presenting the factors that affect decision-making about vaccination against human influenza among a group of patients with cardiovascular diseases. An additional aim is to determined whether there are differences between the groups of patients involving medical and socio-organizational factors.

Materials and method. Pilot studies were carried out in a Cardiology Clinic in a non-public healthcare institution in Białystok, northeast Poland, in 2018. The research tool was an independently designed 8-question questionnaire. A comparison was made between the groups distinguished during the study: patients revaccinated regularly, not vaccinated at all, and those who were vaccinated once, but refused to continue.

Results. The questionnaire was answered by 71 respondents. The major medical conditions the patients included: "recurrent viral infections" (73.2\%), "all influenza symptoms intensified" (64.8\%), and "the number of cases per year" (81.7\%). Among the social factors, the following were the most significant: "media information" (69\%), "vaccination among friends and family" (69\%), "information received from a doctor" (64\%), as well as "knowledge about influenza" (74\%).

Conclusions. The groups of respondents varied significantly in their chosen decision-making factors. The regularly revaccinated pointed out a bigger significance and quantity of factors motivating for vaccination, compared to other patients. The respondents who have never been vaccinated gave a higher rank to the reasons for not doing so, compared to patients who refused to revaccinate.
\end{abstract}

\section{Key words}

vaccinations, influenza, decision-making factors, cardiovascular diseases

\section{INTRODUCTION}

In Poland, very few people receive vaccinations against human influenza. Data of the National Institute of Public Health National Institute of Hygiene (NIPH - NIH) shows that in the 2017 flu season only 3.4\% Poles received vaccination, making it the smallest group in the European Union [1]. The same year brought a peak of influenza and flu-like cases in the amount of almost 3.8 million. In the last few years, morbidity as well as the number of hospitalized cases have been increasing systematically. It is enough to mention that at the beginning of 2018, the average daily incidence of the disease equaled 88 cases for every 100 thousand people $[2,3]$.

Influenza is one of the most common diseases of the autumn-winter season which affects the majority of the Polish population. The biggest risk involves children below 4-6 years of age, and people over 60-65, but the disease also poses a serious threat to chronically ill patients, regardless of their age. The most common complication of influenza is pneumonia; however, an increase in mortality has also been observed among patients with cardiovascular diseases during and after an epidemic of influenza. [4, 5] Hence, we can speak of distinguished risk groups, i.e. people more prone to the incidence of the disease than others. Elderly patients with

Address for correspondence: Agnieszka Katarzyna Choińska, Medical University, Białystok, Poland

E-mail: akchoinska@gmail.com

Received: 17 November 2018; accepted: 29 December 2018; first published: 21 March 2019 cardiovascular diseases especially fall into this category. [4]

This article takes up the issue of the attitudes of this group of patients towards vaccination against influenza. What various medical and socio-organizational factors affect the decisionmaking tied to vaccinating against influenza? The answer to this question is important since it indicates the strategies for preventive and organizational actions, with reference to the groups of patients more prone to the incidence of the disease. Knowing what influences the motivation of the patients, on the one hand, can help to evaluate their educational needs, and on the other, their expectations from the healthcare institutions $[6,7,8]$.

\section{MATERIALS AND METHOD}

Pilot studies were carried out in a Cardiology Clinic of a non-public healthcare institution in Białystok, northeast Poland, between January - June 2018. The research tool was an independently designed 8-question questionnaire and a demographic profile of the respondents. Thematic areas were chosen which were then developed into tabular questions with a 5-point Likert scale. This allowed the respondent to assign a certain level of importance to his/ her answers.

The first two questions concerned the morbidity of cardiovascular diseases and influenza. The respondents were then asked which of the mentioned factors: first medical connected with experiencing influenza and flu-like diseases, 
and then socio-organizational, influenced their decision whether to vaccinate or not, and to what degree. The question was also addressed to the non-vaccinated respondents, and concerned the reasons for their refusal to be vaccinated. However, the respondents who had been vaccinated at least once were given questions regarding evaluation of the vaccination effects.

The basic research question undertaken in this article is: "Are there any differences between the groups of respondents involved in the investigation in their choice of factors that determine their influenza vaccination decisions?"

This article presents selected aspects of the investigation. Statistical analysis was conducted in such a way that it allowed the obtaining of answers to the stated research problem. The IBM SPSS Statistic 23 package was used to analyze the frequency, perform the Mann-Whitney U tests, Kruskal-Wallis nonparametric variance analysis and exact Fisher tests, as well as $x^{2}$ for one sample. The accepted level of significance was the classic threshold of $\alpha=0.05$.

The study involved 71 patients: 45 women $(63.4 \%)$ and 26 men $(36.6 \%)$ aged between $29-83$ years $(M=63.24 ; S D=9.94)$. Among those questioned, 8 people $(11.3 \%)$ were rural inhabitants and 63 (88.7\%) were urban inhabitants.

The vast majority of the respondents reported the following cardiovascular diseases: hypertension, coronary disease, heart arrhythmia, whereas other diseases occurred in a relatively minor group of subjects. In general, when the number of diseases was summed up, 35 people (49.3\%) suffered only from one illness while the remaining 36 (50.7\%) had more than one disease. Two people had 5 diseases. In addition, apart from their cardiovascular diseases, patients also declared other problems such as: diabetes, asthma, thyroid and rheumatic diseases. The patients also evaluated their frequency of flu morbidity. The most common answer was "Once every two years" - 26 people (36.6\%), the answer "Infrequently" - 20 patients (28.2\%). 10 (14.1\%) respondents admitted to "Once a year", and only one person indicated the "More than once a year" response. The option "I don't get ill" was declared by 13 patients (18.3\%) among all the subjects. Although the last mentioned group of respondents did not declare the incidence of flu, they belonged to the risk group, and were thus subject to analysis.

Furthermore, the studied population of patients did not display a uniform attitude to vaccination. Categories of respondents with different opinions were then distinguished. Three groups of respondents were indicated, based on their particular experience and history of vaccinations: a) vaccinated regularly (35.2\%), b) vaccinated once but refusing to continue (21.1\%), and c) never vaccinated (43.7\%).

\section{RESULTS}

Factors affecting vaccination decisions in each group of respondents. First analyzed was the frequency of indicating particular medical factors which could have influenced the respondents' influenza vaccination decisions in the three distinguished groups (continuing vaccination/ refusing to continue/non-vaccinated). As a result of $x^{2}$ tests, two statistically significant differences were found - in the case of "recurrent viral infections" (relapses of flu between periods of good health) $(V=0.45)$ and "severity of all symptoms" $(V=0.31)$. These were most commonly indicated in the regularly vaccinating group of cardiological patients. The strength of the recorded effects was moderately large. In terms of other factors, no differences were recorded.

The analysis of socio-organizational factors indicated two statistically significant results: "information in the media" $(V=0.34)$ and "vaccination among friends, family or neighbours" $(V=0.31)$. They were indicated more often by the regularly vaccinated people, less often by the never-vaccinated and least often by people who refused to revaccinate. The strength of the recorded effects was moderately large. The "information received from a doctor/specialist" factor was also indicated most often by the regularly revaccinating. This response confirms the patients' confidence in the doctor. The strength of this effect was rather low, as indicated by the Cramer's $V$ coefficient $(V=0.27)$. In terms of the remaining variables, no difference was observed (Tab. 1).

Table 1. Medical and socio-organizational factors and vaccination decisions according to the group of respondents: revaccinating/resigning from revaccination/non-vaccinated

\begin{tabular}{|c|c|c|c|c|c|c|}
\hline \multicolumn{7}{|c|}{ History of vaccination } \\
\hline Factors & Indicators & & $\begin{array}{c}\text { Never } \\
\text { vaccinated }\end{array}$ & $\begin{array}{l}\text { Vaccinated } \\
\text { but refused } \\
\text { to continue }\end{array}$ & $\begin{array}{l}\text { Revaccin- } \\
\text { ating } \\
\text { regularly }\end{array}$ & Test results \\
\hline \multirow{4}{*}{$\begin{array}{l}\text { recurrent viral } \\
\text { infections }\end{array}$} & \multirow{2}{*}{$\begin{array}{l}\text { Not } \\
\text { indicated }\end{array}$} & $N$ & 13 & 6 & 0 & \multirow{4}{*}{$\begin{array}{c}X^{2}(2)=14.1 \\
p=0.00 \\
V=0.45\end{array}$} \\
\hline & & $\%$ & $41.9 \%$ & $40.0 \%$ & $0.0 \%$ & \\
\hline & \multirow{2}{*}{ Indicated } & $N$ & 18 & 9 & 25 & \\
\hline & & $\%$ & $58.1 \%$ & $60.0 \%$ & $100 \%$ & \\
\hline \multirow{4}{*}{$\begin{array}{l}\text { severity of all } \\
\text { symptoms }\end{array}$} & \multirow{2}{*}{$\begin{array}{l}\text { Not } \\
\text { indicated }\end{array}$} & $N$ & 13 & 8 & 4 & \multirow{4}{*}{$\begin{array}{c}X^{2}(2)=6.8 \\
p=0.03 \\
V=0.31\end{array}$} \\
\hline & & $\%$ & $41.9 \%$ & $53.3 \%$ & $16.0 \%$ & \\
\hline & \multirow{2}{*}{ Indicated } & $N$ & 18 & 7 & 21 & \\
\hline & & $\%$ & $58.1 \%$ & $46.7 \%$ & $84.0 \%$ & \\
\hline \multirow{4}{*}{$\begin{array}{l}\text { media } \\
\text { information }\end{array}$} & \multirow{2}{*}{$\begin{array}{l}\text { Not } \\
\text { indicated }\end{array}$} & $N$ & 11 & 8 & 3 & \multirow{4}{*}{$\begin{array}{c}X^{2}(2)=8.0 \\
p=0.02 \\
V=0.34\end{array}$} \\
\hline & & $\%$ & $35.5 \%$ & $53.3 \%$ & $12.0 \%$ & \\
\hline & \multirow{2}{*}{ Indicated } & $N$ & 20 & 7 & 22 & \\
\hline & & $\%$ & $64.5 \%$ & $46.7 \%$ & $88.0 \%$ & \\
\hline \multirow{4}{*}{$\begin{array}{l}\text { vaccination } \\
\text { among friends } \\
\text { and family }\end{array}$} & \multirow{2}{*}{$\begin{array}{l}\text { Not } \\
\text { indicated }\end{array}$} & $N$ & 12 & 7 & 3 & \multirow{4}{*}{$\begin{array}{c}x^{2}(2)=6.8 \\
p=0.03 \\
V=0.31\end{array}$} \\
\hline & & $\%$ & $38.7 \%$ & $46.7 \%$ & $12.0 \%$ & \\
\hline & \multirow{2}{*}{ Indicated } & $N$ & 19 & 8 & 22 & \\
\hline & & $\%$ & $61.3 \%$ & $53.3 \%$ & $88.0 \%$ & \\
\hline \multirow{4}{*}{$\begin{array}{l}\text { information } \\
\text { received from } \\
\text { a doctor / } \\
\text { specialist }\end{array}$} & \multirow{2}{*}{$\begin{array}{l}\text { Not } \\
\text { indicated }\end{array}$} & $N$ & 13 & 8 & 5 & \multirow{4}{*}{$\begin{array}{c}X^{2}(2)=5.2 \\
p=0.08 \\
V=0.27\end{array}$} \\
\hline & & $\%$ & $41.9 \%$ & $53.3 \%$ & $20.0 \%$ & \\
\hline & \multirow{2}{*}{ Indicated } & $N$ & 18 & 7 & 20 & \\
\hline & & $\%$ & $58.1 \%$ & $46.7 \%$ & $80.0 \%$ & \\
\hline
\end{tabular}

Evaluation of particular factors according to groups of respondents. The quantitative aspect, i.e. the sum of the points allocated to all the medical and socio-organizational factors, was also evaluated. 0 points were given for no indication, while every other choice was allocated the number of points chosen by the respondent on the 5-level Likert scale. The Kruskal-Wallis test showed statistically significant results, which allowed performance of the post-hoc DunnSidak test. In both categories, medical $(\mathrm{H}(2)=15.6$; $\mathrm{p}<$ $0.001)$ and socio-organizational $(\mathrm{H}(2)=12.7 ; \mathrm{p}=0.002)$, two statistically significant differences were noted between the people regularly vaccinating against human influenza and the group of patients without any vaccination experience, as well as the group who refuse to revaccinate. No differences were found for the last two groups of patients. 
In addition, analysis of frequency for the three groups of cardiolgical patients showed that these factors were more important for the regularly vaccinating patients, compared to the other groups. The greatest decision value was linked to medical factors, such as "the number of cases per year" and "recurrent viral infections"; these received the same rank from $32.0 \%$ of respondents, and "severity of all symptoms" was indicated by $36.0 \%$ of regularly vaccinated patients who gave it four points on the Likert scale. The answer "frequent doctor's appointments" received the lowest value of three, chosen by $20.0 \%$ of respondents.

An analogous frequency analysis designed for additional factors revealed four factors that influenced the vaccination decisions of cardiological patients: "media information", "vaccination among friends, family and neighbours" were chosen by $32.0 \%$ patients, "other diseases" were indicated by $28.0 \%$ of those polled, and all three of these received a rank of four. The highest rated, 5-point response in this group - "information received from a doctor/specialist" was indicated by $20.0 \%$ of patients.

The never-vaccinated respondents and the group refusing to revaccinate indicated the lowest ranks for the abovementioned factors. Detailed results are summarized in Table 2.

Vaccination and declared number of diseases. In order to discover whether any correlation existed between the number of declared cardiovascular diseases and the influenza vaccination decision, the $x^{2}$ tests were applied. The results, however, were not even close to being statistically significant. It was then assumed that people with one disease, and those with more than one disease, did not differ in terms of making a decision about vaccination. From this, the conclusion can be drawn that a plurality of diseases does not necessarily encourage people to vaccinate against influenza.

It was also examined whether the importance given to the studied motivating factors was different in the groups with one and with more diseases. A series of Mann-Whitney U tests were performed. Only two differences were discovered: in the factors "when the self-treatment methods do not help" and "high fever". In both cases, higher values were recorded in the group of patients with one disease. The strength of both effects was rather low $(r=0.21 ; r=0.22)$. In terms of the other eight factors, no differences were noticed.

Analyses were also performed for the socio-organizational factors. Only one difference was found - for "information received from a doctor/specialist", with a higher rank noted in the group with more than one disease. The strength of the recorded effect was rather low and not significant $(r=0.23)$.

Causes for deciding against vaccination and their rank. The final stage of the study compared the group of respondents who had never been vaccinated with those who refused to revaccinate, to discover whether they assigned the same value of significance to the causes they gave for their decisions. For all five listed causes, the group who never vaccinated pointed to a higher rank of the causes in a 5-point Likert scale in the following order: "lack of belief in the effectiveness of vaccination" (35.5\% of patients) and "fear of complications" (32.3\% of patients), received five points on the scale; "social opinion denying the value of vaccination" ( $16.1 \%$ of patients) - four points on the same scale; "lack of knowledge about vaccines" ( $25.8 \%$ of patients) - three points on the scale. The opposite tendency was observed for "lack of knowledge about vaccination points", which was not indicated by $54.8 \%$ of respondents. All these factors were the main motivation for refusing vaccination against human influenza, which was perceived as daunting and uncertain regarding health effects.

\section{DISCUSSION}

The obtained results show that there was a major group of respondents (64.8\%) who did not vaccinate against influenza. This is a well-known tendency, confirmed by both nationwide and international statistics. Admittedly, the tendency to vaccinate increases with age and, as the NIPH reports inform, some significant differences in decisions about vaccination between particular age groups have now been observed for several years. For example, in the age group of 15-65, influenza morbidity equaled about 6.5 thousand people in every 100 thousand inhabitants, and the percentage of the vaccinated reached about 1.4 . However, among the people above 65 , influenza and flu-like diseases morbidity was more than 5.5 thousand in every 100 thousand inhabitants, and the highest indicator from the whole population was noted - almost $7 \%$ of those vaccinated [1].

A survey conducted in Slovakia, with results close to Polish experience, indicated that only $19 \%$ of people submitted to vaccination in the research sample, which included 623 respondents in elderly age. The surveyed indicated the factors which mostly affected their decisions about vaccination. They involved mostly recommendations of doctors and nurses $(65 \%)$, healthcare (12\%), earlier positive experiences $(10 \%)$, and the influence of advertisements in the media (3\%). However, a high acceptance of vaccinations was significantly correlated to chronic diseases, such as lung diseases, cardiovascular diseases and diabetes, as well as to the advanced age of the respondents [9].

An investigation conducted in Japan also explicitly stated that the indicators of vaccination against influenza are dropping systematically. In rural societies, the respondents admitted that positive information received from reliable and easily accessible sources allowed for making quicker decisions. The significant factors which motivate people to get vaccinated were the government's decisive actions, good medical healthcare and expectations from institutions and workplaces. The survey pointed out that two groups of respondents were vaccinated most frequently: children and school students who received vaccinations because it was their parents' decision, as well as elderly people who were willing to reduce the morbidity and thus the amount of dismissals caused by influenza [5].

The results of own research presented in the current article indicate that the factors affecting the attitude towards vaccination were of interest to all groups of respondents selected in the survey. The significance of the factors was subject to individual evaluation of surveyed patients who, with the help of Likert scale, rated the rank of particular decisionmaking conditions. It turned out that the research sample is not as uniform as it is often suggested by many research papers in which the respondents are divided dichotomously into followers and opponents of vaccination. Public and even scientific debates often follow that scheme. However, patients exhibit more diverse characteristics; even at the verybeginning of analyzing the collected data the patients were divided into 
Table 2. The importance of particular factors affecting vaccination decisions

\begin{tabular}{|c|c|c|c|c|c|c|c|c|}
\hline $\begin{array}{l}\text { Medical and socio- } \\
\text { organizational factors }\end{array}$ & Groups of respondents & & Not chosen & $\begin{array}{c}1 \\
\text { Low rank }\end{array}$ & 2 & 3 & 4 & $\begin{array}{l}5 \\
\text { High rank }\end{array}$ \\
\hline \multirow{6}{*}{ number of cases per year } & \multirow{2}{*}{ Revaccinating regularly } & $N$ & 4 & 5 & 2 & 1 & 5 & 8 \\
\hline & & $\%$ & $16.0 \%$ & $20.0 \%$ & $8.0 \%$ & $4.0 \%$ & $20.0 \%$ & $32.0 \%$ \\
\hline & \multirow{2}{*}{ Vaccinated but refused to continue } & $N$ & 9 & 27 & 5 & 2 & 0 & 3 \\
\hline & & $\%$ & $19.6 \%$ & $58.7 \%$ & $10.9 \%$ & $4.3 \%$ & $0.0 \%$ & $6.5 \%$ \\
\hline & \multirow{2}{*}{ Never vaccinated } & $N$ & 4 & 22 & 3 & 2 & 0 & 0 \\
\hline & & $\%$ & $12.9 \%$ & $71.0 \%$ & $9.7 \%$ & $6.5 \%$ & $0, .0 \%$ & $0.0 \%$ \\
\hline \multirow{5}{*}{ recurrent viral infections } & \multirow{2}{*}{ Revaccinating regularly } & $N$ & 0 & 1 & 5 & 6 & 5 & 8 \\
\hline & & $\%$ & $0.0 \%$ & $4.0 \%$ & $20.0 \%$ & $24.0 \%$ & $20.0 \%$ & $32.0 \%$ \\
\hline & \multirow{2}{*}{ Vaccinated but refused to continue } & $N$ & 19 & 16 & 4 & 5 & 0 & 2 \\
\hline & & $\%$ & $41.3 \%$ & $34.8 \%$ & $8.7 \%$ & $10.9 \%$ & $0.0 \%$ & $4.3 \%$ \\
\hline & Never vaccinated & $N$ & 13 & 11 & 3 & 3 & 0 & 1 \\
\hline \multirow{6}{*}{ severity of all symptoms } & \multirow{2}{*}{ Revaccinating regularly } & $N$ & 4 & 2 & 1 & 3 & 9 & 6 \\
\hline & & $\%$ & $16.0 \%$ & $8.0 \%$ & $4.0 \%$ & $12.0 \%$ & $36.0 \%$ & $24.0 \%$ \\
\hline & \multirow{2}{*}{ Vaccinated but refused to continue } & $N$ & 21 & 9 & 5 & 5 & 4 & 2 \\
\hline & & $\%$ & $45.7 \%$ & $19.6 \%$ & $10.9 \%$ & $10.9 \%$ & $8.7 \%$ & $4.3 \%$ \\
\hline & \multirow{2}{*}{ Never vaccinated } & $N$ & 13 & 8 & 2 & 5 & 3 & 0 \\
\hline & & $\%$ & $41.9 \%$ & $25.8 \%$ & $6.5 \%$ & $16.1 \%$ & $9.7 \%$ & $0.0 \%$ \\
\hline \multirow{5}{*}{$\begin{array}{l}\text { frequent doctor's } \\
\text { appointments }\end{array}$} & \multirow{2}{*}{ Revaccinating regularly } & $N$ & 5 & 3 & 4 & 5 & 4 & 4 \\
\hline & & $\%$ & $20.0 \%$ & $12.0 \%$ & $16.0 \%$ & $20.0 \%$ & $16.0 \%$ & $16.0 \%$ \\
\hline & \multirow{2}{*}{ Vaccinated but refused to continue } & $N$ & 16 & 16 & 5 & 6 & 2 & 1 \\
\hline & & $\%$ & $34.8 \%$ & $34.8 \%$ & $10.9 \%$ & $13.0 \%$ & $4.3 \%$ & $2.2 \%$ \\
\hline & Never vaccinated & $N$ & 9 & 14 & 2 & 5 & 1 & 0 \\
\hline \multirow{5}{*}{ media information } & Revaccinating regularly & $\%$ & $12.0 \%$ & $16.0 \%$ & $12.0 \%$ & $12.0 \%$ & $32.0 \%$ & $16.0 \%$ \\
\hline & \multirow{2}{*}{ Vaccinated but refused to continue } & $N$ & 19 & 16 & 1 & 2 & 5 & 3 \\
\hline & & $\%$ & $41.3 \%$ & $34.8 \%$ & $2.2 \%$ & $4.3 \%$ & $10.9 \%$ & $6.5 \%$ \\
\hline & \multirow{2}{*}{ Never vaccinated } & $N$ & 11 & 12 & 1 & 1 & 4 & 2 \\
\hline & & $\%$ & $35.5 \%$ & $38.7 \%$ & $3.2 \%$ & $3.2 \%$ & $12.9 \%$ & $6.5 \%$ \\
\hline & Revacrinating regularly & $N$ & 3 & 6 & 0 & 4 & 8 & 4 \\
\hline & nevaccinating regurany & $\%$ & $12.0 \%$ & $24.0 \%$ & $0.0 \%$ & $16.0 \%$ & $32.0 \%$ & $16.0 \%$ \\
\hline vaccination among friends & Vaccinated but refused to continue & $N$ & 19 & 11 & 6 & 4 & 4 & 2 \\
\hline & 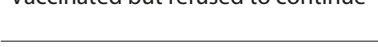 & $\%$ & $41.3 \%$ & $23.9 \%$ & $13.0 \%$ & $8.7 \%$ & $8.7 \%$ & $4.3 \%$ \\
\hline & Never vaccinated & $N$ & 12 & 7 & 5 & 3 & 2 & 2 \\
\hline & & $\%$ & $38.7 \%$ & $22.6 \%$ & $16.1 \%$ & $9.7 \%$ & $6.5 \%$ & $6.5 \%$ \\
\hline & Revaccinating regularly & $N$ & 5 & 2 & 4 & 4 & 7 & 3 \\
\hline & Revaccinating regulanty & $\%$ & $20.0 \%$ & $8.0 \%$ & $16.0 \%$ & $16.0 \%$ & $28.0 \%$ & $12.0 \%$ \\
\hline other diseases & Vaccinated hut rofused to continue & $N$ & 19 & 15 & 5 & 3 & 2 & 2 \\
\hline otner alseases & vaccinated but rerused to continue & $\%$ & $41.3 \%$ & $32.6 \%$ & $10.9 \%$ & $6.5 \%$ & $4.3 \%$ & $4.3 \%$ \\
\hline & Never vaccinated & $N$ & 14 & 11 & 4 & 1 & 1 & 0 \\
\hline & Tvever vaccirlated & $\%$ & $45.2 \%$ & $35.5 \%$ & $12.9 \%$ & $3.2 \%$ & $3.2 \%$ & $0.0 \%$ \\
\hline & Revaccinating regularly & $N$ & 5 & 3 & 4 & 4 & 4 & 5 \\
\hline & Nevaceintanty & $\%$ & $20.0 \%$ & $12.0 \%$ & $16.0 \%$ & $16.0 \%$ & $16.0 \%$ & $20.0 \%$ \\
\hline information received from a & Vaccinated but refused to continue & $N$ & 21 & 15 & 1 & 3 & 3 & 3 \\
\hline doctor/specialist & & $\%$ & $45.7 \%$ & $32.6 \%$ & $2.2 \%$ & $6.5 \%$ & $6.5 \%$ & $6.5 \%$ \\
\hline & Never vacrinated & $N$ & 13 & 11 & 0 & 3 & 3 & 1 \\
\hline & Never vaccinated & $\%$ & $41.9 \%$ & $35.5 \%$ & $0.0 \%$ & $9.7 \%$ & $9.7 \%$ & $3.2 \%$ \\
\hline
\end{tabular}


three groups (revaccinated regularly, vaccinated once but without continuation, never vaccinated) in which everyone was characterized by their own experiences and vaccination history, taking into consideration particular demographic features of the surveyed patients (Tab. 1). Undoubtedly, an increase in population would bring more information about particular categories of respondents and would even allow for the creation of sub-groups for comparison. However, it is not only about quantitative trends but also about those resulting from deeper preferences and expectations of the patients regarding actions of medical institutions, as well as social influence on decisions of the diseased who are often feeling lost in their health experience. Such an approach to the topic gives a deeper view on the situation and reveals hidden motivational conditions differing from medicallyoriented grounds $[7,10]$.

Furthermore, people regularly receiving vaccination were characterized by a greater commitment in choosing the same factors than the remaining groups. The major medical determinants included "recurring viral infections", "severity of all symptoms" and "number of cases per year". Among the social factors, the group of regularly revaccinated patients chose the following answers: "information in the media", "vaccination among friends and family", "information received from a doctor", as well as "knowledge about influenza". They were also given the highest rank of motivational value.

On the other hand, the never-vaccinated gave causes for which they were not willing to vaccinate. It was most often the "lack of belief in the effectiveness of vaccination", "lack of knowledge about vaccines", "social opinion denying the value of vaccination" and "fear of complications". The significance of those reasons was surprisingly strong, especially since the opinions were given by the ill and often by people reaching retirement age. However, the same reasons indicated by the group of vaccinated but not willing to continue were less significant, and scored lower rates of interest and motivational strength. It can therefore be concluded that although the experience of vaccination melts the extremely negative attitude against vaccines, it does not fully explain why the patients choose to resign from it.

The presented results correspond with another investigation carried out in Kraków, Poland, in 2013, on a sample of 103 respondents at retirement age [11]. At that time, the knowledge, beliefs and behavior connected with vaccination in general and in the context of influenza vaccination were analyzed. According to that investigation, a significant motivational factor happened to be the "doctor's suggestion" (71.4\%), but the social influence was also strong as in, for example "suggestion from family" (31.6\%). The same investigation also showed that a significant group of non-vaccinated patients mentioned reasons for which they did not vaccinate: "lack of interest in vaccination" (67.8\%) and "lack of knowledge about it" (69.5\%), many patients were under "a negative opinion of family and friends" (19.6\%). The current investigation, as well as those conducted earlier, showed that the medical authority was not the only dominant motivational and conditioning strength. The social, media and organizational circumstances of the closest environment should also be taken into consideration, and although they are less significant, they determine the health awareness of the population [12]. Studies by Polish authors underline that the relationships between social ties and health condition has to be taken into consideration because social support is often provided by groups in which people go through consecutive stages of life, being involved in social networks where they can often find help and practical actions $[13,14,15]$.

A significant item of information from the respondents was a clear declaration of the importance of knowledge about vaccinations against influenza. The patients admitted that a lack of knowledge made it impossible to fully identify and evaluate the effects of a vaccination in various aspects: the frequency of influenza, observing the post-vaccination complications, as well as complications after an illness. Such factors were considered an indicator of low significance, especially in the eyes of the respondents who were once vaccinated but do not revaccinate anymore, and thus the factors could not directly affect the decision to not carry on with revaccination.

A surprise in the investigation was that it did not indicate any correlation between the increase in declared diseases and an increased tendency to vaccinate among patients with cardiovascular diseases. This is then especially worth noting since the average age was about 63 years, which increases the possibility of a respondent being chronically ill, and thus in a group at risk from influenza. Retirement age also assumes the greatest participation of patients in vaccinations against influenza [9]. This can be explained by the fact that for some respondents declaring lower material status, the price of a vaccine is a significant factor, especially in a situation when they have to take into account the medicament expenses caused by the plurality of other illnesses from which they suffer. It might be that some deeper quality analysis of motivation and encouraging/discouraging factors of economical character would provide more data necessary for investigating the issue more closely, and thus allow the creation of preventative and promotional strategies directed mainly to the risk groups [16].

How, then, can patients from a risk group be reached? First of all, the answer could be intensified education directed at existing connections between their own health and their susceptibility to influenza and flu-like diseases [17]. The presented investigation showed that one of the statistically significant motivational factors of an organizational character was "information received from a doctor/specialist". That factor combines the evaluation of health with an indication for vaccination, although it was significant only for people who revaccinated regularly.

Secondly, the development of patients' health awareness should be aimed at acquiring knowledge about the impact of influenza on the formation and/or severity of cardiovascular diseases in the form of, for example, myocarditis, and heart failure, among others $[6,9,10]$. Research confirming the effectiveness of vaccination in reducing ischemic heart disease has been widely described for years in international and Polish literature [6]. In the USA, this indicator was very high and estimated to be about $67 \%$ in the group of vaccinated patients, compared to control samples. Furthermore, analyses of the influence of influenza vaccination on cardiovascular diseases $[18,19]$ and other accompanying diseases, such as stroke, are constantly being carried out. All such research, often performed on big samples of respondents under longterm observation, undoubtedly confirms the effectiveness of vaccination in the fight against diseases, and the reduction of sudden morbidity cases, for example, myocardial infarction [16]. Particularly underlined was the beneficial influence of 
vaccination on patients with arrhythmia or myocarditis, and the protective effect of vaccination in lowering the indicator of mortality caused by heart diseases $[6,15,20]$.

However, such information reaches patients with great difficulty, they are not aware of these dependences, and therefore cannot recognize that the risk of having influenza increases the danger of developing a cardiovascular or another disease. Most of the investigated respondents knew only the common opinions on vaccination which were conditioned socially and by the family. Many of them did not see the difference between influenza and flu-like disease, and could not observe post-vaccination complications. The postulate to develop "health competence" and practice "functional health knowledge" [21] is therefore still valid. Seeing influenza as a dangerous disease, as well as estimating one's own risk of having it, and treating vaccination as an efficient method of preventing this disease, increases the probability of getting vaccinated.

A result of the current investigation was spontaneous opinion expressed by the younger and more educated respondents, which underlay the importance of the commercialization of medicine. The pharmaceutical sector was especially evaluated critically, for which the advertising of vaccination, in opinion of the respondents, is only a marketing action aimed at a wider audience. This is the reason why the mentioned respondents publicly demonstrate their lack of trust and thus ignore vaccination [12].

Hence, it appears that the patients' educational needs are diverse and the stand alone statement: "We should educate" - with no planned strategy, is insufficient. On the one hand, along with an increase in education, the individualization of patients' needs becomes stronger, on the other hand, the interaction of factors affecting the decision-making is becoming increasingly dynamic, which results in both aspects enriching the network of health determinants. Insightful investigations are worth noting in which both quantitative and qualitative methods are used to analyze the interaction of conditions and determinants of structural character (mechanisms of health and social politics), shaped hierarchically (healthcare system) in relation to personal factors and local environments. Although such widelymade analyses show that the basic barriers connected with vaccination, especially of people above 65 years of age and with chronic diseases, have been overcome in developing countries, they still remain a problem in countries with a low or medium income. However, even in wealthier regions, there are still groups of non-vaccinated people, caused by earlier experiences of influenza complications. An overview of the literature clearly confirms a significant share of factors from outside the home sector which affect the vaccination decision. Next to the previously mentioned personal beliefs of respondents, cultural and historical conditions are now considered to play an important role $[10,22]$.

A limitation of the this investigation was the small population of patients, which resulted in the inability to point out the differences in the choice of motivators for vaccination against influenza between the group declaring one cardiovascular disease and the patients declaring several. Hence, collecting a greater amount of data and detailed information about these groups of patients would allow for a study of higher significance. However, the data obtained to-date allowed the establishment of future directions for the analyses of factors affecting the decisions of cardiological patients.
Undoubtedly, the major issues include the risk groups and the degree of their participation in vaccinations against human influenza. An important health strategy is a continuous monitoring of the impact of vaccinations on cardiovascular diseases, and reducing complications after influenza in healthy subjects and patients. In addition, the study and analysis of the importance of social influences on vaccination decisions of cardiological patients in selected populations should focus not only on the support which the patient receives in their close social environments, but also on those activities that involve institutional and media influence on the health awareness of citizens.

\section{CONCLUSIONS}

1. The conducted investigation shows that the population of people in the risk group had a diversity of attitudes and opinions on vaccination against influenza.

2. The three selected and statistically tested groups of respondents differed in terms of choosing the factors motivating both medical and socio-organizational categories.

3. The vaccinated people indicated a higher number and importance of motivating factors for vaccination, compared to the other groups of patients.

4. The respondents who had never been vaccinated gave a higher rank to the reasons why they do not get vaccinated, compared to the patients who were not willing to revaccinate.

5. The patients who admittedly to being vaccinated once but for various reasons did not continue, proved to be a particularly interesting group for analysis and wider investigation. The obtained intermediate results indicate that for deeper analysis of this group, the research sample should be enlarged in order to better describe this heterogeneous group and to identify any possible subpopulations.

\section{REFERENCES}

1. Sytuacja zdrowotna ludności Polski i jej uwarunkowania, B. Wojtynia, P. Goryński (red) Narodowy Instytut Zdrowia Publicznego - Państwowy Zakład Higieny. Warszawa 2016: 235-243.

2.Zdrowie i ochrona zdrowia w 2016 roku. Główny Urząd Statystyczny. Warszawa 2017.

3.https://www.pzh.gov.pl/serwisy-temetyczne/gromadzenie-danychszczepienia/

4.https://www.mpz.mz.gov.pl/mapy-potrzeb-zdrowotnych-dokumennty/ mapy-dla30-grup-chorob/

5. Daisuke M, Masako S, Kotaro O, Nagato K., Isao W, Yoshiyuki W. Factorsassociated with influenza vaccination status of residents of ruralcommunity in Japan. BMC Public Health. 2011; (11): 149.

6. Gorczyca-Michta I, Wożakowska-Kapłon B. Grypa a choroby układu sercowo-naczyniowego, Kardiologia Polska. 2010; 68(10): 1168-1171.

7. Udell JA, Zawi R, Bhatt DL, et al. Association between influenza vaccination and cardiovascular outcomes in high-risk patients: a metaanalysis. JAMA, 2013; (310): 1711-720.

8. Piepoli M.F, et al. Wytyczne ESC dotyczące prewencji chorób układu sercowo-naczyniowego w praktyce klinicznej w 2016 roku. Kardiologia Polska. 2016; 74(9): 821-936.

9. Martinkowa J, Kabatova O, Putekova S. Factors affecting seniors' attitudes to vaccination against influenza. Kontakt. 2017; (19): 24-28.

10. Nagata JM,Hernandes-Ramos I, Kurup AS, Albrecht D, VivasTprrealba C, Franco-Paredes C, Social determinant of health and seasonal influenza vaccination in adults $>65$ years: a systematic review of qualitative and quantitative data, BMC Public Health 2011; (13): 388 
11.Szczerbińska K, Barańska I, Brzyski P, Ocetkiewicz T, Kurowska I, Wiedza, przekonania i zachowania osób starszych wobec szczepień ochronnych zalecanych w starszym wieku, Gerontologia Polska. 2014; (2): 51-61.

12. Centrum Badania Opinii Społecznej. Komunikat z badań. Stosunek do szczepień przeciwko grypie. Warszawa 2013.

13. Piątkowski W (red), Zdrowie - choroba - społeczeństwo. Studia z socjologii medycyny, Wydawnictwo UMCS, Lublin 2004.

14. Taranowicz I. Między racjonalnością modelu profesjonalnego a racjonalnością laicką. Wyzwania socjologii medycyny. [w:] Ostrowska A, Skrzypek M, (red) Socjologia medycyny w Polsce z perspektywy półwiecza. Nurty badawcze i najważniejsze osiągnięcia, perspektywy rozwoju. Wydawnictwo IFiS PAN. Warszawa 2015.s.131n.

15. Heszen I, Zmienność wymiarów zdrowia na przestrzeni życia człowieka, [w:] Psychologiczny wymiar zdrowia, kryzysu i choroby, (red.) D Kubacka-Jasiecka, T Ostrowski,. Wydawnictwo UJ, Kraków 2005: 21-37.

16. Poland GA. Valuing Influenza Vaccine: Medical, Economic, and SocialBenefits, Clinical Infectious Diseases. 2009; (48): 299-301.
17. Promocja zdrowia dla osób starszych. Podręcznik dla promotorów zdrowia (red.) S. Golinowska. Wydawnictwo Naukowe Scholaris. Warszawa 2017: 13-25, 137, 189.

18. Frobert O, Gotberg M, Angeras O, i in. Design and rationale for the Influenza vaccination After Myocardial Infarction (IAMI) trial. A registry-based randomized clinical trial, American Heart Journal 2017; (189): 94-102.

19. Asghar Z, Coupland C, Siriwardena N. Influenza vaccination and risk of stroke: selfcontrolledcase - seriesstudy, Vaccine. 2015; (33): 5458-5463.

20. Chiang $\mathrm{MH}, \mathrm{Wu} \mathrm{HH}$, Shih CJ, Chen YT, Kuo SC, Chen TL. Association between influenza vaccination and reduced risks of major dverse cardiovascularevents in elderly patients.American Heart Journal. 2017; (193): 1-7.

21. Iwanowicz E. „HealthLiteracy” jako jedno ze współczesnych wyzwań zdrowia publicznego, Medycyna Pracy. 2009; 60(5): 427-437.

22. Piątkowski W (red). Socjologia z medycyną. W kręgu myśli naukowej Magdaleny Sokołowskiej, Wydawnictwo IFiS PAN, Warszawa 2010. 